\title{
A criança e a escola da floresta: história da escolarização da infância na cidade de Sinop - Mato Grosso (1973-1979)
}

The child and the forest school: history of schooling from childhood in the city of Sinop - Mato Grosso (1973-1979)

\author{
Elizabeth Figueiredo de Sá \\ Universidade Federal de Mato Grosso \\ Josiane Brolo Rohden \\ Universidade Federal de Rondônia
}

\section{Resumo}

Este artigo trata da implantação da primeira Escola de Sinop, Mato Grosso, constituída concomitantemente com a cidade, durante seus primeiros anos de colonização (19731979), cuja migração em especial, procedia do sul do país. O trabalho volta-se para a História da Infância, de forma a discutir como se organizou um sistema educacional provindo de costumes, tradições, para formar os futuros cidadãos desejáveis inquirindo a cultura escolar e as representações de infância que atendessem à concepção de uma escola que se assemelhasse à cultura sulista, situada geograficamente em plena região de floresta amazônica. Para tal, fundamentando-nos em Michel De Certeau, reconhecemos na cultura escolar produzida pelos sujeitos da instituição a possibilidade de concebermos a história de um cotidiano caracterizado pela criação, invenção daquilo que os sujeitos faziam com os produtos que thes eram fabricados. Desta forma, estratégias de práticas intencionais estavam constantemente em conflito com táticas de subversão no interior da escola.

Palavras-chave: Escolarização da infância. Cultura escolar. Colonização.

\section{Abstract}

This article deals with the establishment of the first school of Sinop, MatoGrosso, formed concurrently with the city during its early years of colonization (1973-1979), whose migration, in particular, was from the South of the country. The work refers to the History of Childhood, in order to discuss how organized an educational system coming from customs, traditions, to form the desirable future citizens asking the school culture and representations of childhood which complied with the design of a school that resembled southern culture, situated geographically in the middle region of the Amazon forest. To this end, basing us on Michel De Certeau, we recognize in school culture produced by the subject of the institution the possibility of devising the story of adaily life characterized by creation, invention of what the people did with their products that were made for them. In this way, intentional practices strategies were constantly in conflict with tactics of subversion inside the school.

Keywords: Schooling of children. School culture. Colonization. 
Acho que o quintal onde a gente brincou é maior do que a cidade. A gente só descobre isso depois de grande. A gente descobre que o tamanho das coisas há que ser medido pela intimidade que temos com as coisas. (MANOEL DE BARROS, 2008).

Nos versos de Manoel de Barros, ecoa a voz do poeta para a importância da história de nossa infância, a história das nossas vidas, daquela história que a 'gente' percebe sua importância e o 'tamanho das coisas' somente depois 'de grande', daquela história, cujo quintal 'onde a gente brincava' se escondia muitos 'tesouros', muitos 'perigos', muitas 'histórias'. Uma história que temos intimidade e que por isto revela um grande valor. Uma história guardada no passado, mas, refletida no presente e anunciada no futuro. Uma história desta forma, não compreendida de forma linear, mas, como propõe Walter Benjamin (1987), como base no entrelace das diferentes temporalidades a partir dos vestígios do passado.

A história que nos propomos a narrar reflete os resquícios da infância e a escolarização destinada a elas - crianças-migrantes que chegaram a Sinop, cidade localizada ao norte de Mato Grosso, cuja história é marcada pelo movimento de migração de milhares de pessoas que deixaram suas cidades de origem, especialmente do sul do país em busca de uma "Terra Prometida", de um 'Eldorado' em meio à floresta amazônica mato-grossense.

A história de muitas crianças, revelando, no presente, o quão 'grande' era o 'quintal' de suas casas, o 'quintal' da escola, repleto de vestígios da infância e da sua escolarização, possibilitaram a análise e discussão, neste trabalho, repleto de invenções e reinvenções de um cotidiano escolar em meio a uma floresta.

\section{O processo de colonização de Sinop - MT: "em busca de um futuro melhor"}

Durante a década de 1970, a região Norte de Mato Grosso passou por um processo acentuado de migração. Muitos migrantes, principalmente do Sul do país, deixaram suas cidades de origem, para "ocupar" os espaços "vazios" das terras norte mato-grossense, na busca de maiores oportunidades e de um futuro melhor. 
Desde o Governo Getúlio Vargas, com o chamado projeto Marcha para Oestel, que visava ocupar e desenvolver, no interior do país, o processo de ocupação da última grande fronteira agrícola do país - a Amazônia brasileira², começou a 'ganhar forma'.

A partir de 1964, os governos militares almejando a continuidade do processo de integrar a Amazônia à economia nacional e com o intuito de atenuar a crise na economia rural que se acentuava principalmente nas regiões Sul, Sudeste e Nordeste, voltaram-se para a ampliação de políticas públicas que pudessem concretizar o processo de ocupação territorial da Amazônia.

Para tal finalidade, foram criados órgãos específicos, que coordenavam a instalação e implantação de projetos que visavam à expansão da região, incentivando a aquisição de terras e, com isto, promovia o deslocamento de um grande número de trabalhadores migrantes.

Neste contexto, o surgimento da cidade de Sinop, localizada na região Norte de Mato Grosso, encontrava-se nesse processo de ocupação da Amazônia do final do século XX. Trata-se de uma cidade fruto de uma colonização privada, liderada pela empresa que deu origem ao nome da cidade: Colonizadora Sinop S/A - Sociedade Imobiliária do Noroeste do Paraná. A Empresa citada, beneficiada pelos incentivos fiscais pela parceria do Estado Federal, responsável por toda a infraestrutura necessária e pelas políticas e órgãos criados para acelerar o processo de colonização, adquire uma extensa área de terra denominada, posteriormente, de Gleba Celeste ${ }^{3}$, onde seria, então, iniciado um novo projeto de colonização, entre eles, a cidade de Sinop.

Compreender a relação das conjunturas políticas e sociais do período, o processo de migração do norte mato-grossense, a formação da cidade de Sinop, assim como os reflexos da sociedade em construção juntamente com a instituição escolar, nos leva a tecer uma discussão sobre como a escola estava organizada, que saberes eram necessários ser mantidos e repassados pela escola, que discurso inferia sobre a relevância da escolarização das crianças do ensino primário, e, deste modo, que infância e que educação foi destinada a elas. 


\section{A escola da floresta: vestígios da história da primeira instituição escolar de Sinop e das práticas por ela produzidas}

A primeira escola de Sinop surgiu a partir de um movimento próprio: das astúcias humanas, dos primeiros migrantes que, chegando à localidade, se deparam com mais uma promessa: uma escola que não existia! Assim, em regime de mutirão, eles mesmos decidem instaurar um sistema educacional, com aquilo que tinham e, principalmente com o que consideravam por 'escola' aos modos daquilo que conheciam no sul do país, tendo como influência a Empresa Colonizadora e a lgreja Católica através das irmãs da Congregação Santo Nome de Maria, trazidas de Maringá, Paraná pelos colonizadores, especialmente para direcionar os trabalhos sociais e educacionais na Gleba Celeste.

Trata-se de uma escola cuja história em sua especificidade traz à cena um projeto diferente de escola que conviveu numa mesma temporalidade Brasil afora (SILVA, 2012) com outros projetos de escola pública, o que possibilita, desta forma, a emergência de se pensar cada Instituição Escolar na sua singularidade, na intimidade de cada história.

Assim, este trabalho sugere uma discussão sobre o discurso nacional no que se refere ao contexto educacional na tentativa de romper com a ideia de se ter "[...] diferentes projetos de escolarização ancorados num discurso nacional que insiste em homogeneizar, seja nas estatísticas, seja nas propostas pedagógicas." (SILVA, 2012 , p. 2), uma vez que se pretende enfatizar a singularidade da Instituição em estudo, o que nos permite contrapor ao discurso da existência de uma escola brasileira 'única'.

Contudo, consideramos necessário discutir o contexto histórico em que o país vivia na década de 1970 assim como o discurso pedagógico oficial, para que possamos aguçar a questão proposta. De acordo com Germano (201 1, p. 160, grifos do autor), nessa década, o clima em que o país vivia se caracterizava, ao mesmo tempo, "[...] por uma combinação de medo da repressão do Estado e de euforia em decorrência do crescimento econômico."

Dessa forma, no que se refere à educação, de acordo com o discurso nacional era preciso, adequar a escola para esses fins - era necessário instrumentalizar, preparar desde a infância os cidadãos para que se tornassem 
futuros trabalhadores habilitados a receber um país em acelerado crescimento econômico/industrial que dependeria de muita 'mão de obra'.

Mesmo porque, naquele momento, a política educacional, segundo Germano (201 1), estava incompatível com a ideia de "Brasil-potência", de acordo com o próprio Ministro da Educação da época, Jarbas Passarinho, visto que, em 1971, quase 30\% das crianças de 7 a 14 anos não tinham acesso à escola; a evasão e a repetência assumiam dimensões alarmantes: para cada mil crianças que entravam na $1^{a}$ série do primário, em 1961, menos da metade (446) chegava à $2^{a}$ série e somente 56 ingressavam no ensino superior; em 1972, a taxa de perdas era da ordem de $76 \%$, só no primário.

Como explica Germano (201 1), tratava-se de um quadro que não poderia continuar, pois, à medida que o sistema escolar se expandia os empregadores tendiam a exigir uma elevação dos requisitos educacionais da força de trabalho e, nas palavras de Passarinho (1985 apud Germano 201 1, p. 168), "[...] era um dever de Estado, a democratização do ensino era um duplo imperativo: um imperativo ético e um imperativo políico."

Com isso, a chamada Reforma do Ensino de $1^{\circ}$ e de $2^{\circ}$ graus, oficialmente denominada de Lei de Diretrizes e Bases para o Ensino de $1^{\circ}$ e $2^{\circ}$ Graus - Lei n. ${ }^{\circ}$ 5.692, de 11 de agosto de 1971, foi fruto das reformas que marcaram as décadas de 1960 e 1970, período do regime militar. Ocorreu a criação de convênios de cooperação e apoio técnico entre o Ministério da Educação e Cultura do Brasil e a Agency for International Development dos Estados Unidos, identificados pelas siglas MEC-USAID.

Germano (201 1, p. 180) esclarece que a Lei n. ${ }^{\circ} 5.692 / 71$, ao ser sancionada, assumia uma configuração radical referente à preparação para o trabalho, haja vista sua consonância com as necessidades do mercado. Para tanto, o artigo $5^{\circ}, \S 2^{\circ}$, alínea a, referente à formação especial prevista pelo currículo, "[...] terá o objetivo de sondagem de aptidões e iniciação para o trabalho, no ensino de $1^{\circ} \mathrm{grau}$, e de habilitação profissional, no ensino de $2^{\circ}$ grau."

Assim, os reflexos de uma sociedade que necessitava de uma educação que fosse consoante com o momento político em que o país vivia, resultaram nas Reformas Educacionais do ensino primário e secundário, cujo principal objetivo era formar 'cidadãos' aos padrões do governo vigente e 
trabalhadores qualificados, uma vez que o ensino deveria estar totalmente voltado para o tecnicismo.

Contudo, a máxima adotada neste trabalho é de que cada Instituição Escolar é única, singular, e, portanto, merecedora de ser objeto de estudo. (SANFELICE, 2007). Dessa forma, propõe romper com os discursos nacionais que generalizam a escola brasileira, sem levar em consideração a forma como historicamente se constituiu e se constitui diuturnamente cada uma delas. É certo que a Lei em vigor, na década estudada, pretendeu constituir de modo generalizador a organização e o funcionamento das escolas, porém os impactos, a forma como cada escola lidou com a Reforma de Ensino só é possível de análise mediante estudos particularizados de cada uma, o que nos impede de tecer uma discussão que ajude a "[...] implodir a ideia de existência de uma escola brasileira." (SILVA, 2012 , p. 2 e 4). No Brasil nunca se conseguiu oferecer à população uma escola 'única' - "[...] as disparidades são marcantes e cada vez mais precisam ser evidenciadas para que possamos superar o vício de falar de um modelo de escola para tratar de modelos de escola que coexistem."

Para tanto, sem a pretensão de reduzir esta pesquisa em conformidade 140 com um discurso pedagógico legitimador e generalizador, nos manteremos a analisar como estava organizada e de que modo funcionava a escola em estudo, mantendo nosso olhar para o cotidiano dessa escola - seu cotidiano e suas reinvenções.

De acordo com as fontes compulsadas na Escola, a exemplo das grades curriculares referentes ao período em análise, podemos constatar como estava organizado o ensino primário, assim como vestígios de práticas escolares produzidas na e para a escola.

No primeiro ano (1973-1974), faz-se necessário pontuar que a pequena escola, a 'escola dos migrantes', funcionava em regime multisseriado. Entretanto, de agosto 1974 a 1979, passou-se a trabalhar em regime seriado. Dessa forma, a organização curricular, de acordo com documentos oficiais encontrados na escola, durante todo período o investigado, no que se refere ao ensino de $1^{a}$ a $4^{a}$ séries do $1^{\circ} \mathrm{Grau}$, era composta pelas disciplinas de Comunicação e Expressão, Iniciação à Ciência, Integração Social/ Estudos Sociais, sendo perceptível de compreensão a partir da análise dos cadernos de alunos e de diários de classes dos professores, que a ênfase do 
ensino privilegiava as disciplinas de Comunicação e Expressão ${ }^{4}$ e a Iniciação à Ciência .

Nas séries iniciais, da $1^{a}$ a $4^{a}$ série do $1^{\circ}$ grau, verificamos que as atividades trabalhadas eram compostas principalmente por 'leituras silenciosas', cópias, ditados, tabuadas, as chamadas contas matemáticas de 'arme e efetue', entre outros exercícios mecânicos, levando o aluno a escrever, inúmeras vezes, letras, sílabas, palavras ou números.

Outra prática comum na $1^{a}$ série do $1^{\circ}$ grau era a cobrança da Leitura. Todos os alunos, ao final do ano letivo, eram submetidos aos exames de leitura, os quais as irmãs chamavam aluno por aluno para ler em voz alta.

Além dos testes de leituras que as irmãs católicas faziam no ano final do ano letivo, outros exames também eram aplicados no decorrer do ano letivo. A partir da $2^{a}$ série do $1^{\circ} \mathrm{grau}$, por exemplo, testes de tabuadas eram exigidos com rigor e de forma muito abstrata, o que se consolidava um ensino pouco efetivo.

Diante disto, conforme pontuamos, as ações voltadas para a prática de leitura 'das palavras', para a escrita, como também para os cálculos eram mais exigidas no interior da sala de aula, desde os anos iniciais da escolarização, o que demonstra e comprova a supremacia da Língua Portuguesa e da Matemática no interior da Instituição.

As disciplinas trabalhadas, segundo exemplos apresentados nos cadernos e nas narrativas obtidas, simplificavam o currículo da escolarização básica, oferecendo o mínimo necessário para que os sujeitos se adequassem à formação técnica, exigidas pelo mercado de trabalho, além das práticas se voltarem para o respeito e ao cultivo das boas maneiras, ao amor ao próximo, à Pátria, à devoção à lgreja Católica.

Desta forma, na escola em investigação, percebemos um ensino voltado para a prática da repetição, para a técnica da memorização e para o silêncio. Além disso, "[...] os conteúdos privilegiavam o sentimento de amor e respeito para com o próximo, ressaltando o modo de agir e tratá-lo com civilidade, preparando a criança para a vida individual e coletiva." (SÁ, 2007, p. 168).

Contudo, retornando às práticas investigadas na Escola em estudo, em relação às que envolviam o cuidado com o corpo, com a Higiene, além dos valores familiares e sociais que exaltassem o regime militar, eram relembrados 
cotidianamente, como por exemplo, após cantar o hino e fazer a oração diária, a Irmã Edita, diretora da escola, pronunciava discursos que faziam alusões aos valores, normas e juízos que eram necessários ser mantidos na escola, na família e na sociedade.

Nesse sentido, percebemos que a educação em Sinop, com a constante influência da colonizadora e da lgreja, buscava aos seus modos, de alguma forma, atender aos propósitos nacionais de uma política social fundamentada pela ideologia tecnicista, para a formação para o trabalho, com o objetivo de 'educar' mentes e corpos que fossem viáveis às expectativas do Estado. Com isso, torna-se evidente que a seleção e a produção do conhecimento sempre estiveram repletas de intencionalidades e, de algum modo, intimamente ligadas às necessidades e interesses "políticos." IGODSON, 2008).

\section{Entre estratégias e táticas: das artes de fazer o cotidiano escolar}

A partir das discussões que pontuamos até o momento, reconhecendo 142 as estratégias de imposição e a lógica do jogo vindo de um lugar, assim como as relações de poder que se configuravam no contexto da escola em análise, partimos do pressuposto de que, sendo a escola um lugar de produção de uma cultura específica, onde ressoavam as mais diferentes experiências cotidianas, havia algo no cotidiano dela que constituía de maneira singular a experiência da escolarização de cada sujeito, mesmo diante dos discursos ordenadores e reguladores daqueles que detinham o poder, da imposição do silêncio, do controle da disciplina, do aprendizado dos conteúdos difundidos na escola, dentre outras ações que constituíam o conjunto de práticas intencionalizadas por um lugar próprio.

A partir desse olhar, reconhecemos na cultura escolar produzida pelos sujeitos da instituição a possibilidade de concebermos a história de um cotidiano marcado pela criação, invenção e reinvenção daquilo que os sujeitos faziam com os produtos que thes eram fabricados. As estratégias de práticas intencionais estavam em conflito com as táticas de subversão e a escola, bem ou mal, lidava com esse processo de tensão, pois não conseguia manter rigorosamente tudo à maneira que lhe convinha, fazendo-se presentes as práticas desviantes que fugiam, escapavam às normas e, muitas vezes, talvez 
na maioria delas, não eram percebidas, ou simplesmente eram vistas como banais, rotineiras, sem 'periculosidade'.

Estado, a lgreja, a Colonizadora acreditavam que a escola era o cenário ideal para a formação da massa, aliás, concepção que ainda circula na educação do nosso país nos dias atuais. Como já dissemos, a concepção de um modelo arquitetônico é capaz de manter o controle, disciplinamento e a ordem entre os sujeitos, mesmo porque "[...] o espaço escolar é um elemento curricular que proporciona a aprendizagem de um conjunto de valores, normas e estímulos que não são determinados pelo currículo formal, mas que fazem parte de uma forma silenciosa de ensino [...]" (SÁ, 2007, p 132), portanto, "[...] o espaço escolar não é neutro, sempre educa." IVIÑNO FRAGO; ESCOLANO, 200 1, p. 75).

A tal modelo arquitetônico Michel Foucault (2009, p. 147) chama de 'panóptico' na sua obra Vigiar e Punir, em virtude de se constituir em local onde todos os controlados e vigiados são sujeitos ao disciplinamento dos corpos, afinal, como ironiza o próprio autor: "Um corpo disciplinado é a base de um gesto eficiente [...] a disciplina define cada uma das relações que o corpo deve manter com o objeto que manipula."

Para Viñao Frago e Escolano (2001), uma determinada leitura da citada obra caracteriza a escola, sobretudo, enquanto espaço limitado, fechado, junto a outras instituições disciplinares de dominação e controle, como, por exemplo, quartéis, hospitais, cárceres. Para os dois autores, porém, essa concepção, por si só, é insuficiente, visto que não contempla as diferentes funções que o espaço escolar desempenha ou deveria desempenhar. A escola é, pois, um espaço demarcado, porém a análise dele enquanto lugar só é possível a partir da consideração histórica daquelas camadas ou elementos que o configuram e definem.

Para tanto, o 'panóptico' que se intentava impor à escola em estudo não contava que teria de lidar com a maneira incisiva da cultura como criação, com as práticas diferenciadas de apropriação desses modelos, os quais resistiam sutilmente, 'dobravam-se sem quebrar' (AZEVEDO; ARAÚJO, 2011 ) e, que então, reinventavam aos seus modos o sentido de estar naquele meio dito por Certeau (1998), podem ser explicadas enquanto táticas, encontradas por aqueles sujeitos para serem usadas como suas armas de combate - a arte do fraco, que "[...] fingia obediência aos poderes estratégicos, mas não 
se iniciava uma guerra explícita contra esses." (AZEVEDO; ARAÚJO, 2011 , p. 483).

Desse modo, se restringíssemos o presente trabalho numa análise das práticas de poder que aconteciam no interior da escola, poderíamos resumir que um dia rotineiro no seu cotidiano era marcado frequentemente pelas mesmas práticas, por um trabalho rígido desenvolvido pelas irmãs católicas em concordância com a metodologia tradicional, de cunho moralista, patriótico e técnico, reflexo externo vindo do momento em que o país vivia.

Devido à metodologia tradicional que se consolidava em sala de aula, percebemos, a partir das fontes analisadas e dos depoimentos colhidos, que, aparentemente, os alunos eram obedientes e servis, mesmo porque a sociedade se comportava dessa forma, refletindo diretamente no contexto escolar.

Por outro lado, um repensar sobre todo esse panóptico criado para disciplinar e formar os cidadãos aos moldes que se eram exigidos, é possível perceber as marcas de um cotidiano em que os 'supostos assujeitados' refaziam, recriavam o lugar em momentos passados imperceptíveis, como já mencionado, em simples situações consideradas banais, ordinárias.

Muitas histórias que burlavam a ordem estabelecida compunham o cotidiano da escola, dentre muitas, elencamos algumas que consideramos interessantes, para perceber como as táticas moviam os sujeitos nas suas artes de fazer, ambíguas, sem localização própria, surgidas das contingências da situação, de modo a aproveitar as brechas do sistema, foram improvisadas, fruto da "[...] inteligibilidade criada no aqui e agora, exigindo inteligência viva, parecendo desprezar modelos preestabelecidos, estando constantemente apreendendo a situação e agindo sobre ela improvisando saídas. (AZEVEDO; ARAÚJO, 201 1):

Devido tanta imposição de disciplina, tinha muita gente que tinha muito medo das irmãs, principalmente os meninos que faziam muita bagunça. Tinha uns que levavam reguada das professoras, mas não adiantava. Ficavam de castigo no milho, tinha que colocar o joelho em cima do milho e não adiantava [...]

Lembro que certa vez, uma menina levou um puxão de orelha, a professora puxou e disse: 'copia, tá todo mundo fazendo!' E ela não copiava, ficava para lá e para cá. Aí, ela não queria fazer e mostrou a língua para a professora, a professora pegou na orelha dela e puxou, ela abriu a boca e gritou: vou contar para a minha 
mãe, foi um fuzuê na sala, porque os pais já não toleravam mais, este comportamento do professor poder ter autoridade para bater. (PONCE, 2012).

Eu lembro que eu gostava muito de ler gibi. Minhas tias, meu pai traziam pra gente ler. Aí a gente trocava muito gibi na escola embora fosse proibido pelas irmãs. (BÉRGAMO, 2012).

A brincadeira do elástico era a preferida, mas teve uma época que as irmãs proibiram porque diziam que era perigoso, mas sempre alguém dava um jeito de levar. Também jogávamos bola apesar das irmãs não gostarem muito para não entrar na sala suados, mas a gente brincava por mais que fosse pouco tempo, aproveitava aquele tempinho para brincar. A gente construía brinquedos, fazia bola de meia para arremessar no palhaço, era sempre a criatividade da gente, porque não tinha outras coisas. (SILVA, 2012).

Assim, com base nos exemplos citados e de muitos outros que dispomos em nossas fontes, entendemos que associar as contribuições de Certeau ( 1998 ) para conhecer as relações e as práticas no espaço escolar "[...] nos permite ver a escola em toda a sua complexidade, e não como simples reprodutora de imposições e regras dos sistemas de ensino e do sistema social mais amplo." (MONTEIRO; CANEN; FONTOURA, 2010, p. 4).

Nesses exemplos, percebemos que existia, sim, o 'receio' da punição, mas em contrapartida se revelava o jogo, que vencia o medo e encontrava nas 'falhas' que iam abrindo brechas na vigilância do poder, promovendo "[...] mobilidade, mas numa docilidade aos azares do tempo, para captar, no vôo, as possibilidades oferecidas por um instante [...]" (CERTEAU, 1998, p. 100) as astúcias, golpes, artes de fazer se faziam presentes, em microdetalhes. Como diria Certeau (1 998, p. 101), "Aí vai caçar. Cria ali surpresas. Consegue estar onde ninguém espera. É astúcia."

Para o mesmo autor, toda atividade humana pode ser considerada cultural, desde que a prática tenha significado para quem a realiza. Assim, não apenas nos depoimentos dos alunos, mas também dos próprios professores, percebemos as 'fugas', as diferentes tentativas de lidar para se ajustarem às políticas que thes eram impostas, indo, dessa forma, reorganizando o cotidiano de suas práticas: 
Imagina, aquele lugar diferente, aquelas cartilhas diferentes, alunos diferentes a cada dia, eu precisava ser artista mesmo! Não tinha material, o estado não mandava, eu tinha que usar era a criatividade. Eu tinha que encontrar uma maneira de ensinar aqueles conteúdos, então eu tentava associar a realidade do que a gente estava vivendo com as minhas aulas, então a minha metodologia era adaptada assim: para ensinar uma letra eu associava a mata, a floresta, os rios, os macacos, até o avião que vinha aqui. [...] Quando o estado começou a mandar cartilha, era eles que escolhiam, a gente não podia escolher com o que queria trabaIhar, então eu fazia assim: as minhas aulas eu fazia sempre como uma história, eram como novelas, todo dia um capítulo porque daí o aluno tinha interesse em vir para a escola e saber o que ia acontecer com o personagem que eu inventava, mexia com a curiosidade deles. [...] As provas vinham prontas. Eram as irmãs que elaboravam, a gente corrigia, mas tinha um modelo com os valores para as correções de cada questão. Não podia deixar os alunos usar borracha no dia da prova. A primeira série não podia usar a borracha. Sabe por quê? Por que elas ficavam desconfiadas que algum professor mudasse a resposta do aluno ou falasse que estava errado e ensinasse o certo. Eu achava um absurdo, meus alunos da primeira série do jeito que fez tinha que deixar. Era ordem da irmã Edita. Parecia um concurso, que não podia errar... Isto foi por uns dois anos, acho que até 77, aí começamos a reclamar [...] e isto foi mudando, mas quem pegou estes primeiros anos, passou por uma escola da vida [...]. (BRAZ, 2011 ).

Às vezes eu pensava se precisava tudo aquilo, se tudo aquilo não era muito rigoroso, mas o que eu podia fazer se eu também recebia ordens! (PAULA, 2012).

Pelos pequenos exemplos, ditos por ex-professoras, é interessante "[... perceber que as posições de 'forte' e 'fraco' podem mudar constantemente, sendo, por exemplo, um professor 'forte' frente ao aluno, mas 'fraco' diante da gestão ou ao sistema de ensino." (MONTEIRO; CANEN; FONTOURA, 2010, p. 4, grifos das autoras).

Nesse contexto, compartilhamos das ideias de Julia (200 1), quando nos diz que:

[...] normas e práticas não podem ser analisadas sem se levar em conta o corpo profissional dos agentes que são chamados a obedecer a essas ordens e, portanto, a utilizar dispositivos 
pedagógicos encarregados de facilitar sua aplicação, a saber os professores primários e os demais professores. UULIA, 2001, p. 10).

Outra questão observada, era a auto-organização dos próprios alunos quando não estavam sob vigilância, trazendo novamente Julia (200 1, p. 10) para o debate, "[...] por cultura escolar é conveniente compreender também, quando é possível as culturas infantis (no sentido antropológico do termo) que se desenvolvem nos pátios de recreio e o afastamento que apresentam em relação às culturas familiares [...]", por isso, é possível inferir que a cultura produzida na família e na sociedade se difere daquela produzida na escola, pelo fato de haver ideias, símbolos, valores que lhes são próprios:

O horário do recreio era o horário de brincar e de comer o lanche. Não era recreio dirigido, então a gente aproveitava para brincar bastante, de correr, mas a irmã não gostava muito porque suava, mas o pátio era grande, ela nem via. Também gostávamos de brincar de 3 mocinhas da Europa: lembro-me ainda hoje: Somos 3 mocinhas da cidade, O que vieram fazer? Muitas coisas! Então faz para nós ver! Então isto era o que mais nós gostávamos de fazer! [...] Brincávamos muito de roda: de Terezinha de Jesus, passava o recreio rodando, tinha aquela cantiga: A menina que tá na roda: A menina que tá na roda, é uma gata espichada, tem a boca de jacaré e a saia remendada! Depois, trocava, ia outra criança no meio. Fazíamos muita brincadeira de roda, eram momentos maravilhosos! (PONCE, 2012).

Julgamos interessante relacionar que, enquanto os professores e a direção da escola buscavam encontrar formas de devolver a harmonia facilitadora e 'apaziguadora' da ordem, os alunos pareciam compreender le assim se organizavam! $\left.\right|^{6}$ que silêncio e barulho conviviam juntos, ordem e desordem não se excluíam", trazendo outras possibilidades de mover-se no mesmo espaço, tornando aquele lugar, de fato, num lugar praticado.

"O recreio que parecia ser o fim do trabalho pedagógico [...] era o inicio da auto-organização [...]" (ALBUQUERQUE, 2006, p. 41) daquelas crianças e jovens, "[...] era o início da negociação de regras em torno de um objetivo comum, era o início de uma convivência social qualitativamente superior $[\ldots]^{\prime \prime}$ daquela imposta em sala de aula. 
Com bolas de meias, latas de óleo e tacos de madeiras para jogar bets $^{8}$, elásticos e qualquer outro artefato que pudesse virar brinquedo, aquelas crianças reinventavam jogos e brincadeiras. E, assim, jogavam com as possibilidades; enquanto a ordem via apenas do alto do seu panóptico a disciplina e o silêncio, as crianças utilizavam-se do que thes era oferecido para recriar a seu modo, o próprio espaço na escola, o que lhes garantiam a possibilidade de ocupação em terras alheais e, portanto, nos momentos de conflito e de combate, as suas vozes se faziam ouvir pelas artes de fazer. Nas palavras de Certeau (1998, p. 95): "Eles metaforizavam a ordem dominante: faziam-na funcionar em outro registro. Permaneciam outros, no interior do sistema que assimilavam e que os assimilava exteriormente. Modificavam-no sem deixá-lo."

Com isso, se fazia uma cultura criada e recriada no espaço escolar, entre trocas, encontros, situações conflituosas, práticas desviantes, não planejadas e, muitas vezes, ignoradas, imperando o silêncio, mas também, sutilmente, ressoavam as vozes que cantavam juntas cirandas e cantigas de roda.

O momento em que aqueles alunos se viam livres da vigilância era o espaço onde conseguiam recriar, "[...] negociar e lutar por sua felicidade, pelos seus desejos, se apropriando de cada fenda, de cada canto, de cada 148 brecha, se esgueirando, escorregando, deslizando." (ALBUQUERQUE, 2006, p. 40). Cada um, à sua maneira, exercia como ninguém suas artes de se fazer sujeito, cada qual com a singularidade que the era própria e, isso, "[...] sem sair do lugar onde tem (tinha ${ }^{9}$ que viver e que impõe (impunha) uma lei, ele aí instaura (instaurava) pluralidade e criatividade. Por uma arte de intermediação ele tira (tirava) daí efeitos imprevistos." (CERTEAU, 1998, p. 93).

Finalmente, se a escola focava na ordem e disciplina, por outro lado seus atores buscavam criar, recriar os modos de se viver naquele espaço. Assim, ao direcionarmos um olhar para a cultura escolar no interior de sua prática, nos lançamos a uma possível compreensão da experiência concreta da vida da escola. Sendo essa experiência compartilhada com todos os que compunham a instituição em investigação, ela se diferenciava na maneira como cada um incorporou tal experiência.

Contudo, há que se referenciar que as mil práticas de fazer ICERTEAU, 1998) não se restringiam aos alunos circunscritos ao espaço escolar, mas se estendia ao 'privado', de seus lares, sob outra espécie de 'vigilância', no caso, a família. Havia sob 'normas e regras' vindas de um lugar, o espaço de fazer, 
os modos de proceder da criatividade cotidiana, as burlas, as fugas, em que as múltiplas invenções e criações davam espaço para uma infância constantemente reinventada, uma verdadeira arte de fazer e de ser criança. Nas sábias palavras de Walter Benjamin:

As crianças formam o seu próprio mundo de coisas, um pequeno mundo inserido no grande. Dever-se-ia ter sempre em vista as normas desse pequeno mundo quando se deseja criar premeditadamente para crianças e não se prefere deixar que a própria atividade - com tudo aquilo que é nela requisito e instrumento encontre por si mesma o caminho até elas. (BENJAMIN, 2009, p. 104).

Diante disso, entende-se, com o filósofo, o quanto a escola e a sociedade, seja no passado ou no presente, devem ser repensadas sob formas de atuar com este 'pequeno mundo'. Mundo onde as coisas são vistas pela ótica da criação, da vida em constante movimento, para que, então, se possa evitar que as coisas ensinadas não perdessem o encantamento, para que o aprender não se restringisse a moldar o corpo e a mente e, consequentemente, para que o processo de escolarização não se tornasse empobrecido, como nos versos do poeta mato-grossense Manoel de Barros, em sua Didática da Invenção:

O rio que fazia uma volta atrás de nossa casa

era a imagem de um vidro mole que fazia uma volta atrás de casa.

Passou um homem depois e disse: Essa volta

que o rio faz por trás de sua casa se chama enseada.

Não era mais a imagem de uma cobra de vidro que fazia uma volta atrás de casa.

Era uma enseada.

Acho que o nome empobreceu a imagem.

(BARROS, 2008, p. 45).

Nesse sentido, a escola, a infância e a pequena cidade que se formava deixavam marcas de invenção e reinvenção do cotidiano. A sobrevivência pedia isso! Homens, mulheres e crianças produziam, aos seus modos, uma história com significados próprios, deixando inscritas no passado marcas de uma história-arte. 


\section{Reflexões finais}

que se intentou nesta investigação foi contribuir para "[...] compreender a escola com base em seu funcionamento interno e nas práticas que disseminou com o intuito de responder às demandas do fazer ordinário da classe, isto é, do trabalho cotidiano em sala de aula, e da relação que estabelecia com a sociedade na qual estava inserida." (VIDAL, 2005, p. 166).

Nesse contexto, a Igreja Católica, juntamente com a colonizadora, desenvolvem na escola um trabalho conjunto, onde a religião, a obediência, o silêncio, a idolatria à Pátria constituíam as bases que fundamentavam os princípios educacionais.

Durante o período cronológico em estudo, pudemos verificar que a organização e o funcionamento da escola em questão tinham como critério seguir os preceitos da educação estabelecida pela Lei de Diretrizes e Bases para o Ensino de $1^{a}$. e $2^{\circ}$ Graus - Lei 5.692, de 11 de agosto de 1971, à qual definia um ensino técnico e mecanicista, visando a preparação do cidadão para o trabalho e em consonância com os interesses do Estado Militar, instaurando, naquele contexto histórico, uma educação moldada às perspectivas do novo cenário urbano-industrial que se constituía no país.

Dessa forma, na documentação pesquisada, nos diversos depoimentos orais coletados e nas fontes iconográficas percebemos as marcas de um ensino em que as atividades estimulavam a memorização e a repetição; o silêncio predominava na sala de aula; onde a Pátria era exaltada todos os dias na tentativa de 'docilizar' mentes e corpos, uma educação embasada na religião, cujos princípios inculcavam valores e juízos morais, enaltecendo com 'glórias' a 'nova' cidade, com o intuito de apresentar na fé o refúgio de consolação e a esperança de dias melhores.

Contudo, no que se refere ao 'panóptico' instituído na escola para controlar, disciplinar, silenciar - "[...] uma prática panóptica a partir de um lugar de onde a vista transforma as forças estranhas em objetos que se podem observar e medir, controlar, portanto, e 'incluir' na sua visão [...]" ICERTEAU, 1998, p. 100), havia, também, na dinâmica da sala de aula, uma produção cultural específica, em que os 'fracos' jogavam sutilmente com os 'fortes', sem entrar em confronto direto, sem ser necessária a imposição dos 'fracos', mas aos seus modos, aos seus jeitos de fazer e com suas mobilidades táticas 
fazendo aparecer suas artes de fazer, conseguiam estar onde ninguém esperava, mobilizando as estratégias do forte, fazendo daquele lugar um espaço, tornando-o, então, um lugar praticado - lugar que movia-se, lugar que se escondia e aparentemente dominado, porém conquistado, recriado e transformado em espaço no mundo (CERTEAU, 1998) daqueles que nele habitavam.

\section{Notas}

1 A Marcha para Oeste foi uma política do governo de Vargas, nascida em 1943 a qual incentiva as pessoas a migrar para a região central do Brasil, na perspectiva de ocupar os "espaços vazios" do país, garantir a segurança das fronteiras e gerar riquezas.

2 Os nove estados que compõem a Amazônia Brasileira são: Acre, Rondônia, Amazonas, Pará, Mato Grosso, Roraima, Amapá, Tocantins, e Maranhão. (PICOLI, 2005).

3 A extensão de terra adquirida pela empresa colonizadora equivalia a, aproximadamente, 645.000 hectares. Denominada de Gleba Celeste, onde seria então dado início ao projeto de colonização das cidades de Sinop, Vera, Carmem e Cláudia.

4 A disciplina de Comunicação e Expressão era a forma como se denominava o ensino da Língua Portuguesa.

5 A disciplina de Iniciação à Ciência era a forma como se denominava o ensino da Matemática.

6 Cf. Albuquerque (2006).

7 Cf. Morin (2004).

$8 \bigcirc$ jogo de Bets ou Tacos é um esporte de rua, que descende do "cricket" britânico. $\bigcirc$ objetivo principal do jogo é rebater a bola lançada pelo jogador adversário, sendo que durante o tempo em que este corre atrás da bola, a dupla que rebateu deve cruzar os bets, também chamados de tacos ou remos, no centro do campo, fazendo, assim, dois pontos cada vez que cruzam os tacos.

9 As palavras entre parênteses foram adicionadas pelas autoras, pelo fato de a concordância do verbo no passado, tempo em que discorremos sobre as nossas reflexões.

\section{Referências}

ALBUQUERQUE, Andréa Serpa. Cultura escolar em movimento: diálogos possíveis. Rio de Janeiro: EdUFF. 2006.

AZEVEDO, Fernando Antônio Gonçalves; ARAÚjO, Clarissa Martins de. Meninos dos sinais e a arte de inventar o cotidiano: personagens hostis ou hostilizados na Grande cena da(s) cidade(s). In: ENCONTRO NACIONAL DA ASSOCIAÇÃO NACIONAL DE ARTES PLÁSTICAS, 20., Rio de Janeiro, 2011 . Anais... Rio de Janeiro: Anpap, 2011 . Disponível 
em: $\quad$ <http://www.anpap.org.br/anais/2011/pdf/ceav/fernando_antonio_goncalvez_ de_azevedo.pdf>Acesso em: 08 fev. 2012

BARROS, Manoel de. Memórias inventadas: as infâncias de Manoel de Barros. São Paulo: Editora Planeta do Brasil, 2008.

BENJAMIN, Walter. Reflexões sobre a criança, o brinquedo e a educação. Tradução Marcus Vinicius Mazzari. 3. ed. São Paulo: Editora 34, 2009.

Magia e técnica, arte e política: ensaios sobre literatura e história da cultura. Tradução Sérgio Paulo Rouanet. 3. ed. São Paulo: Brasiliense, 1987. (Obras Escolhidas, v. 1.)

BERGAMO. Depoimento (oral). Sinop (Mato Grosso). 17 jan. 2012.

BRASIL. Ministério da Educação e Cultura/Conselho Federal de Educação. Lei $\mathbf{n}^{\circ} \mathbf{5 . 6 9 2}$ Lei de Diretrizes e Bases para o Ensino de $1^{\circ}$ E $2^{\circ}$ Graus. Reforma do Ensino de $1^{\circ}$ e $2^{\circ}$ graus. Brasília: Ministério da Educação e Cultura, 11 de agosto de 1971.

BRAZ. Depoimento (oral). Sinop (Mato Grosso). 11 dez. 2011.

CERTEAU, Michel de. A invenção do cotidiano: artes de fazer. Tradução Ephraim Ferreira Alves. 4. ed. Petrópolis: Vozes, 1998, v. 1.

FOUCAULT, Michel. Vigiar e punir: nascimento da prisão. Tradução Raquel Ramalhete. 36. ed. Petrópolis: Vozes, 2009.

GERMANO, José Wellington. Estado Militar e educação no Brasil (1964-1985). 5. ed. São Paulo: Cortez, 2011.

GODSON, Ivor F. Currículo: teoria e história. Tradução Atílio Brunetta. 10. ed. Petrópolis: Vozes, 2008.

JULIA, Dominique. A cultura escolar como objeto Histórico. Tradução Gisele de Souza. Revista Brasileira de História da Educação, Campinas, n. 1, p. 9-44, jan.-jun. 2001.

MATO GROSSO. Escola Estadual Nilza de Oliveira Pipino. Grades da organização curricular de $1^{a}$ a $4^{a}$ séries do $1^{\circ}$ Grau da Escola Nilza de Oliveira Pipino, 1974-1979.. Sinop, MT, dez. 2011 . (Documento do arquivo da Escola Estadual Nilza de Oliveira Pipino).

MONTEIRO, Filomena Monteiro de Arruda; CANEN Ana; FONTOURA, Helena Amaral da. Construindo pontes na formação docente: experiências que se articulam. Revista de Educação Pública, Cuiabá, v. 1, n. 1, p. 1-22, jan./abr. 2010. 
MORIN, Edgar. Os sete saberes necessários à educação do futuro. Tradução Catarina Eleonora F. da Silva e Jeanne Sawaya. São Paulo: Cortez, 2004.

PICOLl, Fiorelo. Amazônia: do mel ao sangue - os extremos da expansão capitalista. Sinop-MT: Fiorelo, 2005.

PONCE. Depoimento (oral). Sinop (Mato Grosso), 23 jan. 2012.

SÁ, Elizabeth Figueiredo de. De criança a aluno: as representações da escolarização da infância em Mato Grosso (1910-1927). Cuiabá: EdUFMT, 2007.

SANFELICE, José Luis. História das instituições escolares. In: NASCIMENTO, Isabel Moura; SANDONO, Wilson; LOMBARDI, José Claudinei; SAVIANI, Dermeval (Org.). Instituições escolares no Brasil: conceito e reconstrução histórica. Campinas: Autores Associados/ HISTEDBR; Sorocaba: UNISO; Ponta Grossa, UEPG, 2007.

PAULA. Depoimento (oral). Sinop (Mato Grosso), 02 fev. 2012.

SILVA. Depoimento (oral). Sinop, (Mato Grosso), 07 fev. 2012.

VIDAL, Diana Gonçalves. Culłuras escolares: estudo sobre práticas de Leitura e escrita na escola pública primária (Brasil e França, final do século XIX). Campinas: Autores Associados, 2005.

VIÑ̃O FRAGO, Antonio; ESCOLANO, Agustín. Currículo, espaço e subjetividade: a arquitetura como programa. Tradução Alfredo Veiga Neto. 2. ed. Rio de Janeiro: DP\&A, 2001.

Profa. Dra. Elizabeth Figueiredo de Sá Universidade Federal de Mato Grosso | Cuiabá Instituto de Educação Coordenadora do Grupo de Pesquisa História da Educação e Memória | GEM E-mail | bethfsa@uol.com.br 


\section{Profa. Ms. Josiane Brolo Rohden Universidade Federal de Rondônia | Vilhena Departamento Acadêmico de Ciências da Educação Grupo de Pesquisa História da Educação e Memória | GEM E-mail | josib_rohden@hotmail.com Recebido 02 out. 2013 Aceito 10 dez. 2013}

